\title{
Feeding on protists and particulates by the leptocephali of the worm eels Myrophis spp. (Teleostei: Anguilliformes: Ophichthidae), and the potential energy contribution of large aloricate protozoa
}

\author{
JOHN JEFFREY GOVONI \\ NOAA, National Ocean Service, National Centers for Coastal Ocean Science, Center for Coastal Fisheries and Habitat \\ Research, 101 Pivers Island Road, Beaufort, NC 28516-9722 USA. E-mail: Jeff.Govoni@ noaa.gov
}

\begin{abstract}
SUMMARY: The food sources of the leptocephali of the teleostean superorder Elopomorpha have been controversial, yet observations on the leptocephali of the worm eels, Myrophis spp. (family Ophichthidae) collected in the northern Gulf of Mexico indicate active, not passive, feeding. Leptocephali had protists in their alimentary canals. Estimates of the physiological energetics of worm eels indicate that large aloricate protozoa including ciliates could provide substantial energy to these leptocephali toward the end of the premetamorphic and metamorphic stages, given the low energy requirements of metamorphosing leptocephali. Global ocean warming will likely force a shift in oceanic food webs; a shift away from large protozoa toward smaller protists is possible. Such a disruption of the oceanic food webs could further compromise the survival of leptocephali.
\end{abstract}

Keywords: Myrophis, leptocephali, feeding, protozoa, ciliates.

RESUMEN: Alimentación de los leptocéfalos de las anguilas gusano Myrophis SpP. (Teleostei: Perciformes: OPHICHTHIDAE) BASADA EN PROTISTAS Y PARTÍCULAS, Y LA POTENCIAL CONTRIBUCIÓN ENERGÉTICA DE LOS GRANDES PROTOZOOS ALORICADOS. - Las fuentes de alimento de los leptocéfalos del superorden de los teleósteos Elopomorpha ha sido controvertida. Sin embargo, las observaciones realizadas en leptocéfalos de las anguilas gusano, Myrophis spp. (Familia Ophichthidae) recolectados en el norte del Golfo de México indican una alimentación activa, no pasiva. Los leptocéfalos tenían protistas en sus tubos digestivos. Las estimaciones de la fisiología energética de las anguilas gusano indican que, dados los bajos requerimientos energéticos de los leptocéfalos durante la metamorfosis, los grandes protozoos ciliados aloricados, incluyendo ciliados, podrían proporcionar sustancial energía a estos leptocéfalos hacia el final de las etapas premetamórficas y metamórficas. El calentamiento global de los océanos es probable que fuerce un cambio en las redes alimenticias oceánicas; y es posible un desplazamiento de los grandes protozoos hacia pequeños protistas. Estas perturbaciones de las redes alimenticias oceánicas podrían poner en peligro la supervivencia de los leptocéfalos.

Palabras clave: Myrophis, leptocéfalos, alimentación, protozoos, ciliados.

\section{INTRODUCTION}

The snake and worm eels, Ophichthidae, are the most diverse family of the true eels, Anguilliformes (McCosker, 1997), inhabiting coastal areas of tropical and warm temperate oceans. Genera of the sub- families Ophichthinae and Myrophinae live in the Pacific, eastern and western Atlantic, and Indian Oceans, and possibly in the Mediterranean Sea, but the genus Myrophis has not been reported in the eastern Atlantic Ocean or Mediterranean (Hureau and Monod, 1973). In the western North Atlantic, 
the ophichthids spawn over outer continental shelves or near continental shelf breaks (J.J. Govoni, unpublished observations of egg distributions). Metamorphosing leptocephali of the ophichthids are found near shore (Harnden et al., 1999; Miller and Tsukamoto, 2004).

The larvae of the elopomorph fishes, the leptocephalus, are exceptional among fishes in their morphology and in their physiological energetics (Miller and Tsukamoto, 2004). The internal and external morphology of leptocephali is different from the typical vertebrate body plan, with a central acellular core matrix of glycosaminoglycan (GAG; Pfeiler, 1999), and a large fluid filled space separating the central core, visceral organs, nerve cord, and central blood vessels from the musculature and integument (Smith, 1984). The energy sources that fuel metabolism and provide growth of leptocephali have been controversial (Smith, 1989).

Several feeding behaviors and food sources for leptocephali have been hypothesized, including pseudo-parasitism (Moser, 1981), dissolved organic matter (DOM) (Pfeiler, 1986; Hulet and Robins, 1989), and particulate organic matter (Pfeiler, 1986; Smith, 1984). No leptocephalus, however, has been found attached to another organism in a parasitic mode of behavior. While the alimentary canal of leptocephali has been reported to be non-functional and occluded (Hulet, 1978), recent evidence indicates that the alimentary canal is fully functional (Tamura et al., 1993; Otake, 1996; Pedersen et al., 2003), and can serve in the uptake of DOM through the endocytotic absorption of seawater containing DOM by the gut epithelium (Otake et al., 1993). Laboratory experiments using DOM-enriched water (Liao and Chang, 2001), however, indicate that concentrations of DOM in the ocean are unlikely to be high enough to meet the nutritional requirements of leptocephali.

There is growing evidence of active feeding of leptocephali both in the ocean and in the laboratory. In the laboratory, late stage leptocephali feed on plankton (Alikunhi and Roa, 1951), squid paste (Mochioka et al., 1993), and shark-egg paste (Tanaka, 2003). In the ocean, leptocephali were found to have ciliates (Otake et al., 1990), larvacean houses (Otake et al., 1993; Mochioka and Iwamizu, 1996), and particulates including copepod fecal pellets (Otake et al., 1990; Otake et al., 1993; Mochioka and Iwamizu, 1996) in their alimentary canals.

Eel leptocephali have peculiar growth stages that register in differing, periodic energy requirements: a period of increasing total length (TL) after yolk absorption; followed by periods of decreasing TL as leptocephali metamorphose to become glass eels. Using tooth morphology and TL, Leiby (1989) classified the growth of ophichthid leptocephali into engyodontic, euryodontic, and metamorphic stages. Engyodontic and euryodontic stages are periods of increasing TL and body mass, while the metamorphic stage is a period of decreasing TL and decreasing body mass (Bishop et al., 2000).

The energy demand of elopomorph leptocephali is low (Bishop and Torres, 1999) owing to the large amount of body mass occupied by the acellular matrix composed of GAG that is subsequently catabolized during the metamorphic stage of decreasing TL(Pfeiler, 1996). The speckled worm eel, Myrophis punctatus, exhibits little change in the wet-weight specific metabolic rate through the euryodontic and metamorphic stages (Pfeiler and Govoni, 1993).

\section{MATERIALS AND METHODS}

\section{Collections and leptocephalus taxonomy}

Leptocephali were removed from collections of larval fishes taken from the continental shelf of the northern Gulf of Mexico (Govoni et al., 1983; 1985; 1986; Govoni and Chester, 1990). Day and night collections were taken at discrete depth intervals and preserved in a 5\% (volume to volume) mixture of $35 \%$ saturated formaldehyde solution in seawater buffered with sodium borate. Leptocephali were identified using the morphological and meristic characters provided by Leiby (1989) and Miller and Tsukamoto (2004).

\section{Alimentary canal content analysis}

Complete alimentary canals were removed and cut open, and the contents washed into standard depression slides. The resulting slurries were drawn into cross-sectionally square and optically flat capillary tubes, which were examined and photographed with transmission and interference contrast light microscopy. Slurries containing large particulates were also examined with scanning electron microscopy following Turner (1984). Organisms were frequently difficult to identify owing to their semi-digested state and cellular rupture or distortion owing to preservation (Leakey et al., 1994; Stoecker et al., 1994). 
TABLE 1. - Contents of the guts of Myrophis spp. leptocephali collected from the northern Gulf of Mexico (IC denotes identification with interference contrast microscopy; SEM denotes identification with scanning electron microscopy).

\begin{tabular}{llcl}
\hline Total length $(\mathrm{mm})$ & \multicolumn{1}{c}{ Taxon } & Examination method & Alimentary canal contents \\
\hline 75 & M. punctatus & SEM & Unidentified particulates \\
64 & M. punctatus & IC & Unidentified particulates \\
64 & M. punctatus & IC/SEM & Unidentified ovoid cells with large nuclei \\
& & & Unidentified ovoid cells \\
& & & Ciliate polykenetids \\
& & Dinoflagellates \\
(incomplete specimen) & M. punctatus & IC & Unidentidied particulates \\
58 & M. punctatus & IC/SEM & 2 copepod fecal pellets \\
(incomplete specimen) & Myrophis spp. & IC/SEM & Unidentified ovoid \\
& & & Unidentified protozoa with oral groove \\
& & & 2 dinoflagellates; \\
& & & Tintinnid, Codonellopsis sp. \\
& & & Rotifer \\
& & Chryptophytes \\
\end{tabular}

Aloricate ciliates were identified using photographs taken by Lynn and Montagnes (1988a,b), Lindholm and Mörk (1990), Lynn et al. (1991) and Crawford (1993).

\section{RESULTS}

\section{Leptocephalus taxonomy}

Seven of the nine leptocephali examined were identified as the leptocephali of the speckled worm eel; two leptocephali were unidentifiable to species level, because of deviations in meristic counts from those given in Leiby (1989). One leptocephalus was late euryodontic; the remaining leptocephai were metamorphic.

\section{Alimentary canal contents}

Six of the nine leptocephali collected contained chime (amorphous, semi-digested food (sensu Govoni et al. (1983)), or unidentified particulates in their guts (Table 1). Three leptocephali contained identifiable organisms or products of digestion. Two leptocephali contained dinoflagellates. Two contained single, double or clumped ovoid cells, $6 \mu \mathrm{m}$ in diameter (Fig. 1a), tentatively identified as foraminiferans. The following cells were found in different individual leptocephali: unidentified, nucleated cells, $13 \mu \mathrm{m}$ in diameter (Fig. 1b); a nucleated cell, $20 \mu \mathrm{m}$ along the long axis, tentatively identified as a cryptophyte (Fig. 1c); an amoeboid cell, $10 \mu \mathrm{m}$ (Fig. 1d); nucleated and flagellated cells, $20 \mu \mathrm{m}$ along the long axis (Fig. 1e, f); a ciliated cell, $100 \mu \mathrm{m}$ along
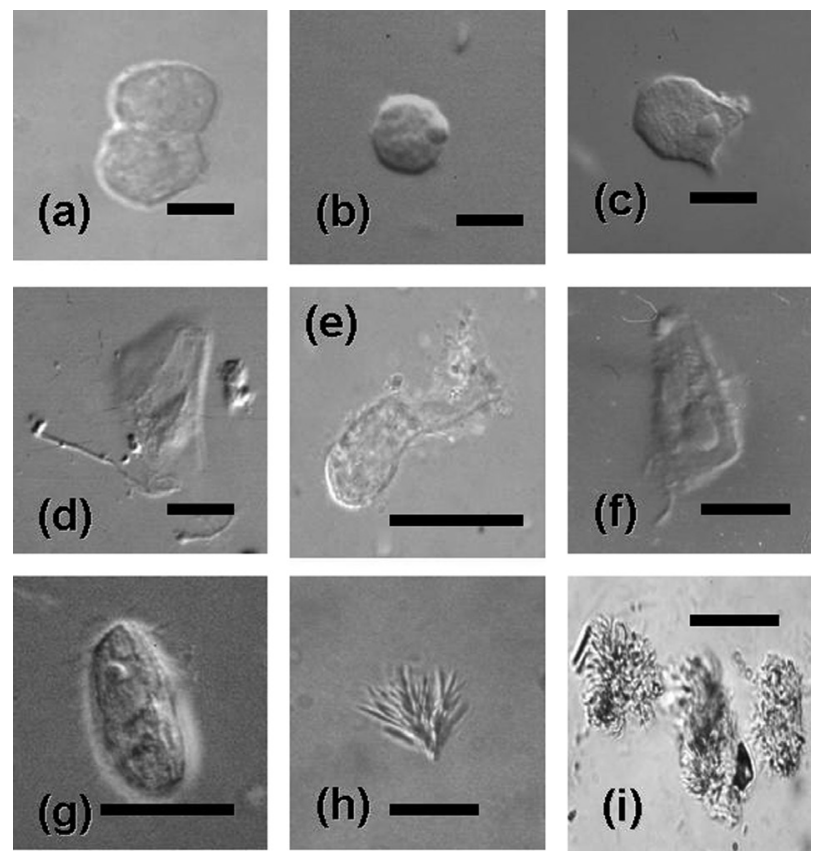

FIG. 1. - Interference contrast photomicrographs of tentatively identified organisms or cell parts from the alimentary canal of a worm eel leptocephalus, Myrophis spp: (a) foraminiferans (scale bar, $5 \mu \mathrm{m}$ ); (b) unidentified ovoid cell (scale bar, $10 \mu \mathrm{m}$ ); (c) chryptophyte (scale bar, $20 \mu \mathrm{m}$ ); (d) amoeba (scale bar, $10 \mu \mathrm{m}$ ); (e) flagellated protozoa (scale bar, $100 \mu \mathrm{m}$ ); (f) flagellated protozoa (scale bar, $100 \mu \mathrm{m}$ ); (g) tentatively identified scuticociliatid ciliate (scale bar, $100 \mu \mathrm{m}$ ); (h) a tentatively identified polykenetid from an oligotrich or choreotrich ciliate (scale bar, $10 \mu \mathrm{m}$ ); (i) tentatively identified polykenetids from oligotrich or choreotrich ciliates (scale bar, $10 \mu \mathrm{m}$ ) .

the long axis, tentatively identified as a scuticociliatid ciliate (Fig. 1g); a tintinnid Codonellopsis spp.; and a rotifer. Another leptocephalus contained many apparent polykenetids (Lynn et al., 1991) of possible oligotrich or choreotrich ciliates (Fig. 1h, i). The exact number of aloricate ciliates is uncertain because of their semi-digested state. Another leptocephalus 

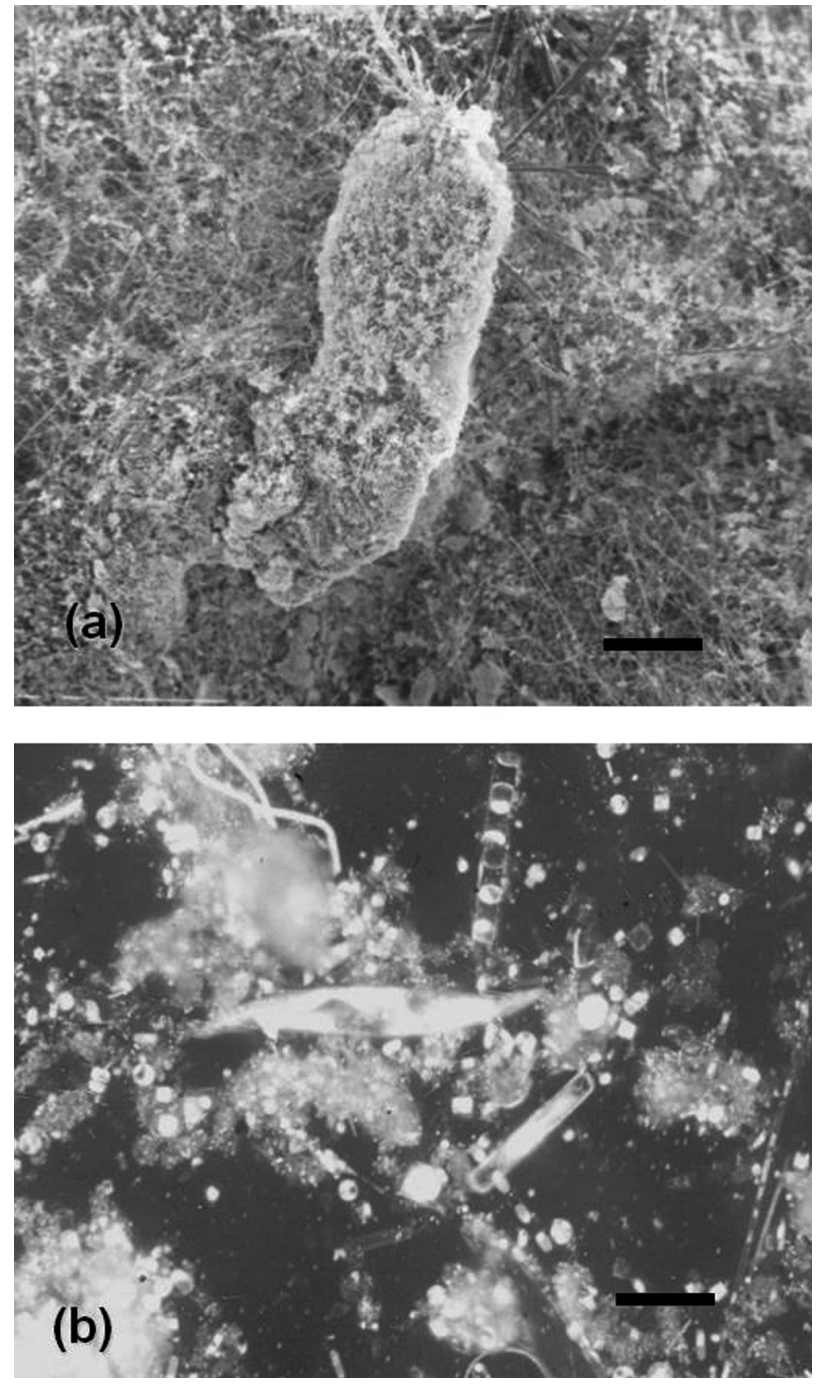

FIG. 2. - (a) Scanning electron micrographs of a copepod pellet from the alimentary canal of a worm eel leptocephalus, Myrophis spp.(scale bar, $150 \mu \mathrm{m}$ ); (b) photomicrograph of the slurry of the fractured fecal pellet (scale bar, $5 \mu \mathrm{m}$ ).

contained a copepod fecal pellet that packaged many bacilli, fragments of centric and chain-forming diatoms (one a fragment of a possible Ceratium spp.) and a dinoflagellate tentatively identified as Gyrodinium (Fig. 2).

\section{DISCUSSION}

Aloricate protozoa are not easily recognized and counted in the alimentary canals of fish larvae and are consequently under-recognized as energy sources for fish larvae including leptocephali. Many of the organisms found in the alimentary canal of worm eels (i.e., diatoms, armored dinoflagellates, tintinninds and rotifers) are common to the diets of other larval fishes in the northern Gulf of Mexico, and these organisms are easily recognized by their remnant hard parts that are refractory to digestion. Ciliates have been reported in the guts of a leptocephalus of Anguilla japonicus (Otake et al., 1990), but these were identified using transmission electron microscopy and were indicated solely by the microfibrillar intracellular supports of their cilia in the digestive residue; they were not enumerated.

There is evidence from larval fishes collected in the ocean (Ohman et al., 1991; Fukami et al., 1999; Figueiredo et al., 2005; Pepin and Dower, 2007) and from laboratory experiments (Hunt von Herbing and Gallager, 2000) that oligotrich or choreotrich ciliates might be important food sources for larval fishes. Aloricate ciliates are preferred food of fish larvae in the laboratory (Hunt von Herbing and Gallager, 2000). Larval fishes are known to selectively feed by discrete feeding strikes on planktonic prey that they can effectively detect with their sensory systems and that they can easily capture given their behavioral responses to prey and their swimming abilities (Govoni et al., 1986). The leptocephali examined here were from the same collections as other larval fishes examined from the northern Gulf of Mexico; consequently, the availability of ciliates as food for leptocephali was the same. Leptocephali are fully capable of sensing (Hulet, 1978; Okamura et al., 2002; Døving and Kasumyan, 2008) and capturing (Pfeiler, 1989) protozoa, including aloricate ciliates. Ciliates are likely to be easy prey for leptocephali in the ocean and they are eaten readily by other larval fishes (Figueiredo et al., 2007). Aloricate ciliates are a preferred food of fish larvae in the laboratory (Hunt von Herbing and Gallager, 2000).

The energy contribution of large protozoa to the physiological energetics of worm eel leptocephali may be substantial. Two leptocephali examined contained food organisms recognized as aloricate protozoa that were larger, ca. 100-200 $\mu \mathrm{m}$, and of higher nutrient (carbon and nitrogen) and energy (Finlay and Uhlig, 1981; Stoecker and Govoni, 1984; Crawford and Stoecker, 1996)) content per cell than are dinoflagellates, diatoms, and small particulates.

Without knowledge of daily feeding periodicity and the evacuation rate of the alimentary canal, an accurate estimate of the daily ration of leptocephali is impossible. Examination of the gut contents indicates alimentary canal contents at a moment in time, whereas feeding and digestion are continuous over some unknown period. A rudimentary estimate of 
the energy contribution of protozoa is, nonetheless, possible. For example, the $64 \mathrm{~mm}$ TL leptocephalus contained large (ciliates and an amoeba) and small (ovoid cells and dinoflagellates) protists. The assumption of five ciliates and one amoeba (large protozoa), and five ovoid cells and two dinoflagellates (small protists), is justified and conservative. With this assumption, and with enthalpy conversions given by Finlay and Uhlig (1981), Stoecker and Govoni(1984), and Crawford and Stoecker (1996) - $44 \mathrm{~J} \mathrm{mg} \mathrm{C}^{-1}$ and $5 \times 10^{-6} \mathrm{mg} \mathrm{C}$ cell $^{-1}$ for ovoid cells, $43 \mathrm{~J} \mathrm{mg} \mathrm{C}^{-1}$ and $3 \times 10^{-6} \mathrm{mg} \mathrm{C}$ cell $^{-1}$ for dinoflagellates, and $47 \mathrm{~J} \mathrm{mg} \mathrm{C}^{-1}$ and $1.25 \times 10^{-4}$ mg C cell ${ }^{-1}$ for the ciliates and the amoeba - the total energy available from the gut contents of this leptocephalus would be $0.04 \mathrm{~J}$. Large protozoa, the amoeba and ciliates, account for most of the energy consumed at this one point in time. This energy contribution, while small when compared with the total, daily energy requirement of leptocephali, indicates that these large protozoa can be physiologically substantial for several reasons: because they are likely to be consumed continuously throughout the feeding period of leptocephali; because the overall energy demand of metamorphic worm eels is low; because energy (matter) for growth is provided by the transformation GAG into morphological (structural) components; and because GAG supplies much of the energy for metabolism. The importance of large protozoa, including ciliates that lack lorica, in the diets of leptocephali and other larval fishes, should be assessed comprehensively (Govoni, 2005).

The survival of eels through early life might be compromised by any decline in the availability of large protozoa as food for elopomorph leptocephali. Ciliates are common, abundant and widely distributed (Stoecker et al., 1989; Lessard and Murrell, 1996), and are key components of oceanic food webs (Pierce and Turner, 1992). Ciliate abundance and availability might change owing to global climate change and its impact on the world's oceans (Miller et al., 2009). A shift in the complexity of primary producers driven by increased temperatures from large diatoms to small dinoflagellates, and consequent shifts in the abundance of heterotrophs and mixotrophs, could change food webs (Friedland et al., 2006; Bonhommeau et al., 2008) in ways that could compromise the availability of large protozoa as food for leptocephali. This would influence negatively the survival of eels through their early life history (Desaunay and Guerault, 1997).

\section{ACKNOWLEDGEMENTS}

I thank R. L. Ferguson for guiding interference contrast microscopy and J. T. Turner for the scanning electron microscopy. I thank M. J. Wuenschel for valuable comments on the energetics of fish larvae and D.W. Evans for energetic conversions. M. J. Wuenschel, J. S. Burke, P. M. Marraro, and B. Knights provided valued reviews of the manuscript. The United States government has the right to retain a nonexclusive, royalty-free license in and to any copyright covering this paper.

\section{REFERENCES}

Alikunhi, K.H. and S.N. Rao. - 1951. Notes on the metamorphosis of Elops saurus Linn. and Megalops cyprinoides (Broussonet) with observations on their growth. J. Zoo. Soc. India, 3: 99-109.

Bishop, R.E. and J.J. Torres. - 1999. Leptocephalus energetics: metabolism and excretion. J. Exp. Biol., 202: 2485-2439.

Bishop, R.E., J.J. Torres and R.E. Crabtree. - 2000. Chemical composition and growth indices in leptocephalus larvae. Mar. Biol., 137: 205-214.

Bonhommeau, S., E. Chassot and E. Rivot. - 2008. Fluctuations in European eel (Anguilla Anguilla) recruitment resulting from environmental changes in the Sargasso Sea. Fish. Oceanogr., 17: $32-44$

Crawford, D.W. - 1993. Some observations on morphological variation in the red-water ciliate Mesodinium rubrum. J. Mar. Biol. Assoc., U. K., 73: 975-978.

Crawford, S. and D.K. Stoecker. - 1996. Carbon content, dark respiration and mortality of the mixotrophic planktonic ciliate Strombidium capitatum. Mar. Biol., 126: 415-422.

Desaunay, Y. and D. Guerault. - 1997. Seasonal and long-term changes in biometrics of eel larvae: a possible relationship between recruitment variation and North Atlantic ecosystem productivity. J. Fish Biol. (Suppl. A), 51: 317-339.

Døving, K.B. and A.O. Kasumyan. - 2008. Chemoreception. In: R.N Fynn and B.G. Kapoor (eds.), Fish Larval Physiology Sensory Physiology, Part 4, Chapter 11, pp. 331-352. Academic Press, New York.

Figueiredo, G.M., R.D.M. Nash and D.J.S. Montagnes. - 2005. The role of the generally unrecognized microprey source as food for larval fish in the Irish Sea. Mar. Biol., 148: 395-404.

Figueiredo, G.M., R.D.M. Nash and D.J.S. Montagnes. - 2007. Do protozoa contribute significantly to the diet of larval fish in the Irish Sea? J. Mar. Biol. Assoc., U. K., 87: 843-850.

Finlay, B.J. and U. Uhlig. - 1981. Calorific and carbon values of marine and freshwater protozoa. Helgol. Wiss. Meeresunters., 34: 401-412.

Friedland, K.D., M. Miller and B. Knights. - 2006. Oceanic changes in the Sasrgasso Sea and declines in recruitment of the European eel. ICES J. Mar. Sci., 64: 519-530.

Fukami, K., A. Watanabe, S. Fujita, K. Yamaoka and T. Nishijima. - 1999. Predation on naked protozoan microzooplankton by fish larvae. Mar. Ecol. Prog. Ser., 185: 285-291.

Govoni, J.J. - 2005. Fisheries Oceanography and the ecology of the early life histories of fishes: a perspective over fifty years. Sci. Mar., 69 (Suppl. 1): 125-137.

Govoni, J.J. and A.J. Chester. - 1990. Diet composition of larval Leiostomus xanthurus in and about the Mississippi River Plume. J. Plankton Res., 12: 819-830.

Govoni, J.J., D.E. Hoss and A.J. Chester. - 1983. Comparative feeding of three species of larval fishes in the northern Gulf of Mexico: Brevoortia patronus, Leiostomus xanthurus, and Micropogonias undulates. Mar. Ecol. Prog. Ser., 13: 189-199.

Govoni, J.J., A.J. Chester, D.E. Hoss and P.B. Ortner. - 1985. An observation of episodic feeding and growth of larval Leios- 
tomus xanthurus in the northern Gulf of Mexico. J. Plankton Res., 7: 137-146.

Govoni, J.J., P.B. Ortner, F. Al-Yamani and L.C. Hill. - 1986. Selective feeding of spot, Leiostomus xanthurus, larvae in the northern Gulf of Mexico. Mar. Ecol. Prog. Ser., 28: 175-183.

Harnden, C.W., R.E. Crabtree and J.M. Shenker. - 1999. Onshore transport of elopomorph leptocephali and glass eels (Pisces: Osteichthyes) in the Florida Keys. Gulf Mexico Sci., 17: 17-26.

Hulet, W.H. - 1978. Structure and functional development of the eel leptocephalus Ariosoma balearicum (DeLa Roche, 1809). Phil. Trans. Roy. Soc. London, Biol. Sci., 252: 107-138.

Hulet, W.H. and C.R. Robins. - 1989. The evolutionary significance of the leptocephalus larva. In: E.B. Böhlke ( ed.), Fishes of the Western North Atlantic, Leptocephali Part 9, Vol. 2, pp. 669677. New Haven, Connecticut: Sears Foundation for Marine Research, Yale University.

Hureau, J.C. and Th. Monod. - 1973. Check-list of the fishes of the north-eastern Atlantic and the Mediterranean. Vol. 1. Presses Universitaires de France, Vendôme.

Hunt von Herbing, I. and S.M. Gallager. - 2000. Foraging behavior in Atlantic cod larvae (Gadus morhua) feeding on a protozoan (Balanion sp.) and a copepod nauplius (Pseudodiaptomus sp.) Mar. Biol., 136: 591-602.

Leakey, R.J.G., P.H. Burkill and M.A. Sleigh. - 1994. A comparison of fixatives for the estimation of abundance and biovolume of marine planktonic ciliate populations. J. Plankton Res., 136: 375-389.

Leiby, M.M. - 1989. Family Ophichthidae: Leptocephali. In: E.B. Böhlke (ed.), Fishes of the Western North Atlantic, Leptocephali, Part 9, Vol. 2, pp. 764-897. New Haven: Sears Foundation for Marine Research, Yale University.

Lessard, E.J. and M.C. Murrell. - 1996. Distribution, abundance and size composition of heterotrophic dinoflagellates and ciliates in the Sargasso Sea near Bermuda. Deep-Sea Res., 43: 1045-1065.

Liao, I.C. and S.L. Chang. - 2001. Induced spawning and larval rearing of Japanese eel, Anguilla japonica in Taiwan. J. Taiwan Fish. Res., 9: 97-108.

Lindholm, T. and A.-C. Mörk. - 1990. Depth maxima of Mesodinium rubrum (Lohmann) Hamburger and Buddenbrock - examples from a stratified Baltic Sea inlet. Sarsia, 75: 53-64.

Lynn, D.H. and D.J.S. Montagnes. - 1988a. Taxonomic descriptions of some conspicuous species of the family strombidiidae (Ciliophora: oligotrichida) from the Isles of Shoals, Gulf of Maine. J. Mar. Biol. Assoc., U. K., 68: 259-276.

Lynn, D.H. and D.J.S. Montagnes. - 1988b. Taxonomic Descriptions of some conspicuous species of strombilidiine ciliates (Ciliophora: choreostichida) from the Isles of Shoals, Gulf of Maine. J. Mar. Biol. Assoc., U. K., 68: 639-658.

Lynn, D.H., D.J.S. Montagnes, T. Dale, G.L. Gilron and S.L. Strom. - 1991. A reassessment of the genus Strombidinopsis (Ciliophora, Choreotrichida) with descriptions of four new planktonic species and remarks on its taxonomy and phylogeny. J. Mar. Biol. Assoc., U. K., 71: 597-612.

McCosker, J.E. - 1997. The osteology, classification, and relationships of the eel family Ophichthidae. Proc. Calif. Acad. Sci., 41: 1-23.

Miller, M.J. and K. Tsukamoto. - 2004. Introduction to leptocephali biology and identification. Ocean Research Institute, University of Tokyo. Tokyo.

Miller, M.J., S. Kimura, K.D. Friedland, B. Knights, H. Kim, D.J. Jeffyman and K. Tsukamoto. - 2009. Review of oceanatmospheric factors in the Atlantic and Pacific oceans influencing spawning and recruitment of anguillid eels. In: A. Haro, T. Avery, K. Beal, J. Cooper, R. Cunjak, M. Dadswell, R. Klauda, C. Moffitt, R. Rulifson and K. Smith (eds.), Challenges for diadromous fishes in a dynamic global environment. Bethesda: American Fisheries Society. Symposium 69: 231-249.

Mochioka, N. and M. Iwamizu. - 1996. Diet of anguilloid larvae: leptocephali feed selectively on larvacean houses and fecal pellets. Mar. Biol., 125: 447-452.

Mochioka, N., M. Iwamizu and T. Kanda. - 1993. Leptocephalus eel larvae will feed in aquaria. Environ. Biol. Fish., 36: 381-384.

Moser, H.G. - 1981. Morphological and functional aspects of marine fish larvae. In: R. Lasker (ed.), Marine fish larvae: morphology, ecology, and relation to fisheries, pp. 90-131. Seattle:
Washington: Washington Sea Grant Program, University of Washington Press.

Ohman, M.D., G.H. Theilacker and S.E. Kaupp. - 1991. Immunochemical detection of predation on ciliate protists by larvae of the northern anchovy (Engraulis mordax) Biol. Bull., 181: 500-504.

Okamura, A., P. Hideo, Y. Yamada, T. Utoh, N. Mikawa, H. Noriyuki and S. Tanaka. - 2002. Development of lateral line organs in leptocephali of the freshwater eel Anguilla japonica (Teleostei, Anguilliformes). J. Morphol., 254: 81-91.

Otake, T. - 1996. Fine structure and function of the alimentary canal in leptocephali of the Japanese eel Anguilla japonica. Fish. Sci., 62: $28-34$

Otake, T., K. Nogami and K. Maruyaka. - 1990. Possible food sources of eel leptocephali. La Mer, 28: 218-224.

Otake, T., K. Nogami and K. Maruyaka. - 1993. Dissolved and particulate organic matter as possible food sources for eel leptocephali. Mar. Ecol. Prog. Ser., 92: 27-34.

Pedersen, B.H., B. Uberscha and T. Kurokawa. - 2003. Digestive response and rates of growth in pre-leptocephalus larvae of the Japanese eel Anguilla japonica reared on artificial diets. Aquaculture, 215: 321-338.

Pepin, P. and J.E. Dower. - 2007. Variability in the trophic position of larval fish in a coastal pelagic ecosystem based on stable isotope analysis. J. Plankton Res., 727-737.

Pfeiler, E. - 1986. Toward an explanation of the developmental strategy in leptocephalus larvae of marine fish. Environ. Biol. Fish., 15: 3-13.

Pfeiler, E. - 1989. Sensory systems and behavior of premetamorphic and metamorphic leptocephalus larvae. Brain Behav. Evol., 34: 25-34.

Pfeiler, E. - 1996. Energetics of metamorphosis in bonefish (Albula sp.) leptocephali: role of keratin sulfate glycosaminoglycan. Fish Physiol. Biochem., 15: 359-362.

Pfeiler, E. - 1999. Developmental physiology of elopomorph leptocephali. Comparative Biochemistry and Physiology . A - Mol. Integr. Physiol., 123: 113-128.

Pfeiler, E. and J.J. Govoni. - 1993. Metabolic rates in early life history stages of elopomorph fishes. Biol. Bull., 185: 277-283.

Pierce, R.W. and J.T. Turner. - 1992. Ecology of planktonic ciliates in marine food webs. Rev. Aquat. Sci., 6: 139-181.

Smith, D.G. - 1984. Elopiformes, Notocanthiformes, and Anguilliformes: Relationships. In: H.G. Moser and W.J. Richards (eds.), Ontogeny and systematics of fishes, pp. 94-102. Lawrence: American Society of Ichthyologist and Herpetologists Special Publication 1

Smith, D.G. - 1989. Introduction to leptocephali. In: E.B. Böhlke (ed.), Fishes of the Western North Atlantic, Leptocephali Part 9 , Volume 2 pp. 657-668. New Haven, Connecticut: Sears Foundation for Marine Research, Yale University.

Stoecker, D.K. and J.J. Govoni. - 1984. Food selection by young larval gulf menhaden (Brevoortia patronus). Mar. Biol., 80: 299-306.

Stoecker, D.K., A. Taniguchi and A.E. Michaels. - 1989. Abundance of autotrophic, mixotrophic and heterotrophic planktonic ciliates in shelf and slope waters. Mar. Ecol. Prog. Ser., 50: 241-254.

Stoecker, D.K., D.J. Gifford, D.J. and M. Putt. - 1994. Preservation of marine planktonic ciliates: losses and cell shrinkage during fixation. Mar. Ecol. Prog. Ser., 110: 293-299.

Tanaka, H. - 2003. Techniques for larval rearing. In: K. Aida., K. Tuskamoto and K. Yamauchi (eds.), Eel Biology, pp. 427-434. Springer Verlag, Tokyo.

Tamura, S., T. Shimuza and S. Ikegami. - 1993. Endocytosis in adult eel intestine: Immulogical detection of phagocytic cells in the surface epithelium. Biol. Bull., 184: 330-337.

Turner, J.T. -1984. Zooplankton feeding ecology: contents of fecal pellets of the copepods Eucalanus pileatus and Paracalanus Quasimodo from continental shelf water of the Gulf of Mexico. Mar. Ecol. Prog. Ser., 15: 27-46.

Scient. ed.: M.P. Olivar.

Received March 13, 2009. Accepted September 7, 2009.

Published online March 12, 2010. 